\title{
Analysis of Covariance in Researching on Influence of the Dormitory Academic Atmosphere on Achievement
}

\author{
Hefang Fan, Shunhou Fan, Chuiling Bai \& Junli Liu \\ College of Science, Tianjin Polytechnic University, Tianjin 300160, China \\ E-mail: fanhefang2006@163.com
}

\begin{abstract}
The construction of the academic atmosphere is directly related to the quality of talents. The approaches of variance analysis and the covariance analysis method of mathematical statistics method are applied in this paper. And the relations of achievement and the academic atmosphere is quantitatively analyzed in terms of the data, which provides a basis of decision-making for university to enhance the academic atmosphere construction.
\end{abstract}

Keywords: The academic atmosphere, Achievement, Variance analysis, Covariance analysis

\section{Introduction}

The learning atmosphere is important for the students' grown - up .The academic atmosphere on the quality of talents can be reflected by student achievement. Dormitory is an important place where college students study and live. The construction of the dormitory style is an important facet of the construction of study style in university. We can often see a phenomenon that the student achievements in the same dormitory are all high or lower. So does the dormitory style have significant effect on student achievement? If have, what laws are the emergence and development of effect.

This paper takes 99 students of18 dormitories of 05 grade telecom special of tianjin polytechnic university as an example, taking student achievement in three academic years as the research object,

The data is provided by teaching section and it is veritable and exact.

Tianjin polytechnic university implements credit hour as academic assessment system. Credit hour of each student can be calculated according to the formula

$$
y=\frac{\sum_{i=1}^{k} s_{i} c_{i}}{\sum_{i=1}^{k} S_{i}}
$$

$S_{i}$ represents the its curriculum credit , $c_{i}$ represents result of final examination of exon I curriculum. $y$ is credit hour.$s_{i}$ comes from teaching plan, $c_{i}$ comes from teaching section .We can calculate credit hour of the first semester, the second term, the second academic year and the third academic year.

\section{Establishment of mathematical model}

The analysis of various table 1 can indicate that the dormitory factor has no significant influence on college entrance examination achievement, that is to say, the arrangement of dormitory is random.

In order to study the relations of scholastic achievement and the style of dormitory study, the style of dormitory that can be looked as a factor of influence on students' achievement denote A,m dormitory can be looked as $\mathrm{m}$ levels. dependent variable is the student credit hour. Where the credit hour of exon $\mathrm{i}$ dormitory exon $\mathrm{j}$ student denote by $y_{i j}$. Because not only the dormitory style study but also foundation differential have influence on credit hour, covariance analysis model can be introduced. We denote college entrance examination achievement (based scores)of exon $\mathrm{j}$ student in exon i dormitory by $z_{i j}$ as 
covariate .let $\alpha_{i}$ to be effect of exon dormitory, $\mu$ is the total effect of $\mathrm{m}$ dormitory, $\mathrm{r}$ is regression coefficient of covariance, the number student of exon dormitory is $n_{i}$, covariance analysis model can be established as follows

$$
\left[\begin{array}{l}
y_{i j}=\mu+a_{i}+r z_{i j}+\varepsilon_{i j} \\
\sum_{i=1}^{m} n_{i} a_{i}=0 \\
\varepsilon_{i j} \square N\left(0, \sigma^{2}\right), i=1,2, \ldots . . m ; j=1,2 \ldots \ldots n_{i}
\end{array}\right.
$$

we have now illustrated model parameters estimation and hypothesis testing of parameters.the detailed derivation he detailed derivation has been studied previously (Li,fang.Analysis of covariance in appraising teaching quality), the result is

$$
\left[\begin{array}{l}
\not \mu=\bar{y}-\hat{r} \bar{z} \\
\alpha_{i}=\left(\overline{y_{i .}}-\bar{y}\right)-\hat{r}\left(\overline{z_{i .}}-\bar{z}\right) \\
\hat{r}=\frac{L_{y z w}}{L_{z z w}}
\end{array}\right.
$$

where $L_{y z w}=\sum_{i=1}^{m} \sum_{j=1}^{n_{i}}\left(y_{i j}-\overline{y_{i .}}\right)\left(z_{i j}-\overline{z_{i}}\right), \quad L_{z z w}=\sum_{i=1}^{m} \sum_{j=1}^{n_{i}}\left(z_{i j}-\overline{z_{i}}\right)^{2}$

$\bar{y}=\frac{1}{n} \sum_{i=1}^{m} \sum_{j=1}^{n_{i}} y_{i j}, \quad \bar{z}=\frac{1}{n} \sum_{i=1}^{m} \sum_{j=1}^{n_{i}} z_{i j}, \quad \overline{y_{i .}}=\frac{1}{n_{i}} \sum_{j=1}^{n_{i}} y_{i j}, \quad \overline{z_{i}}=\frac{1}{n_{i}} \sum_{j=1}^{n_{i}} z_{i j}$,

Whether $\mathrm{m}$ levels of factor A has significant differences can transform into problems of hypothesis testing of parameters

$H_{0}: a_{1}=a_{2}=\ldots=a_{r}=0$ against all alternative hypotheses.

the test statistic is

$$
F=\frac{S S A / f_{A}}{S S E / f_{E}}=\frac{\left[\left(L_{y y T}-\frac{L_{y z T}^{2}}{L_{z z T}}\right)-\left(L_{y y w}-\frac{L_{y z w}}{L_{z z w}}\right)\right] /(m-1)}{\left(L_{y y w}-\frac{L_{y z w}^{2}}{L_{z z w}}\right) /(n-m-2)}
$$

When hypothesis $H_{0}$ is true

$$
F \square F(m-1, n-m-2)
$$

The rejection region under significant level $\alpha$ is

$$
w=\left\{F>F_{a}(m-1, n-m-2)\right\}
$$

to test significant of covariance, that is to say ,to test hypothesis

$$
H_{0 r}: r=0 \leftrightarrow H_{1 r}: r \neq 0
$$

the test statistic is 


$$
F=\frac{S S_{r} / f_{r}}{S S E / f_{E}}=\frac{\frac{L_{y z w}{ }^{2}}{L_{z z w}}}{\left(L_{y y w}-\frac{L_{y z w}{ }^{2}}{L_{z Z W}}\right) /(n-m-2)}
$$

When hypothesis $H_{0 r}$ is true

$$
F \square F(1, n-m-2)
$$

he rejection region under significant level $\alpha$ is

$$
w=\left\{F>F_{a}(1, n-m-2)\right\}
$$

When we use higher mathematic 1s as dependent variable, an analysis of covariance table can be listed

The analysis of various table 2 could indicate that the achievement of higher mathematic 1 is no significant in different dormitory .College entrance examination achievement has significant influence on the achievement of higher mathematic 1 .

When we use higher mathematic 2 s as dependent variable, an analysis of covariance table can be listed.

The above analysis of various table 3 could indicate that the achievement of higher mathematic 2 is significant in different dormitory .College entrance examination achievement has significant influence on the achievement of higher mathematic 2 .

When we use credit hour of the first semester as dependent variable, an analysis of covariance table can be listed

The above analysis of various table 4 could indicate that credit hour of the first semester is no significant in different dormitory .College entrance examination achievement has significant influence on credit hour of the first semester

When we use credit hour of the second semester as dependent variable, an analysis of covariance table can be listed

The analysis of various table 5 could indicate that credit hour of the second semester is significant in different dormitory .college entrance examination achievement has significant influence on credit hour of the second semester

When we use credit hour of the second academic year as dependent variable, an analysis of covariance table can be listed

The analysis of various table 6 could indicate that credit hour of the second academic year is significant in different dormitory .college entrance examination achievement has significant influence on credit hour of the second academic year

When we use credit hour of the third academic year as dependent variable, an analysis of covariance table can be listed.

The analysis of various table 7 could indicate that credit hour of the third academic year is significant in different dormitory. College entrance examination achievement has significant influence on credit hour of the third academic

\section{Result}

From what has been discussion above, we can see that arrangement of dormitory is random when they entered college .dormitory factor has no significant influence on both single curriculum and credit hour at the first semester, the dormitory factor begin to have significant influence on both single curriculum and credit hour at the second semester. We can see that the situation has further developed in the second academic year and in the third academic from the value of $\mathrm{p}$. Many reasons can be account for this phenomenon as follows .Students are not acquaint with each other at the first semester, with the passage of time, the students among the same dormitory influence on each other .The students in the same dormitory are often have the same fancies. We can seen that the dormitory style study have significant influence on student achievement. The construction of the dormitory style should manage as an important key of the construction of study style in university.

\section{References}

DeGracie, j. s. and Fuller, W. A. (1972). Estimation if the slope and analysis of covariance when the concomitant variable is measured with error. 67(1972), 930-937.

Li, fang. (2008). Analysis of covariance in appraising teaching quality. Tianjin polytechnic university journal. 2008, 27(2): 86-87.

Wang, Lingling. Practical statistical methods. 
Table 1.

\begin{tabular}{|c|c|c|c|c|c|}
\hline Source & $\begin{array}{c}\text { Type III Sum } \\
\text { of Squares }\end{array}$ & $\mathrm{df}$ & mean Square & $\mathrm{F}$ & $\mathrm{p}$ \\
\hline Corrected model & $616.623(\mathrm{a})$ & 17 & 36.272 & .637 & .853 \\
\hline Intercept & 451657.232 & 1 & 451657.232 & 7926.193 & .000 \\
\hline dormitory & 616.623 & 17 & 36.272 & .637 & .853 \\
\hline Error & 4615.613 & 81 & 56.983 & & \\
\hline Total & 461269.090 & 99 & & & \\
\hline Corrected Total & 5232.235 & 98 & & & \\
\hline
\end{tabular}

a R Squared $=.118$ (Adjusted R Squared $=-.067$ )

Table 2.

\begin{tabular}{|c|c|c|c|c|c|}
\hline Source & $\begin{array}{c}\text { Type III Sum } \\
\text { of Squares }\end{array}$ & df & mean Square & F & $\mathrm{p}$ \\
\hline Corrected model & $5914.370(\mathrm{a})$ & 18 & 328.576 & 2.452 & .003 \\
\hline Intercept & 1032.105 & 1 & 1032.105 & 7.703 & .007 \\
\hline dormitory & 2984.856 & 17 & 175.580 & 1.310 & .208 \\
\hline Based scores & 2099.600 & 1 & 2099.600 & 15.670 & .000 \\
\hline Error & 10719.267 & 80 & 133.991 & & \\
\hline Total & 619886.000 & 99 & & & \\
\hline Corrected Total & 16633.636 & 98 & & & \\
\hline
\end{tabular}

a R Squared $=.356($ Adjusted R Squared $=.211)$

Table 3.

\begin{tabular}{|c|c|c|c|c|c|}
\hline Source & $\begin{array}{c}\text { Type III Sum } \\
\text { of Squares }\end{array}$ & df & mean Square & F & $\mathrm{p}$ \\
\hline Corrected Model & $11688.339(\mathrm{a})$ & 18 & 649.352 & 2.579 & .002 \\
\hline Intercept & 122.921 & 1 & 122.921 & .488 & .487 \\
\hline dormitory & 8375.332 & 17 & 492.667 & 1.957 & .024 \\
\hline Based scores & 2395.974 & 1 & 2395.974 & 9.517 & .003 \\
\hline Error & 20139.843 & 80 & 251.748 & & \\
\hline Total & 391114.000 & 99 & & & \\
\hline Corrected Total & 31828.182 & 98 & & & \\
\hline
\end{tabular}

a R Squared $=.367$ (Adjusted R Squared $=.225$ ) 
Table 4.

\begin{tabular}{|c|c|c|c|c|c|}
\hline Source & $\begin{array}{c}\text { Type III Sum } \\
\text { of Squares }\end{array}$ & $\mathrm{df}$ & mean Square & $\mathrm{F}$ & $\mathrm{p}$ \\
\hline Corrected Model & $2425.284(\mathrm{a})$ & 18 & 134.738 & 3.934 & .000 \\
\hline Intercept & 2199.758 & 1 & 2199.758 & 64.232 & .000 \\
\hline dormitory & 1350.597 & 17 & 79.447 & 2.320 & .006 \\
\hline Based scores & 805.770 & 1 & 805.770 & 23.528 & .000 \\
\hline Error & 2739.780 & 80 & 34.247 & & \\
\hline Total & 571130.434 & 99 & & & \\
\hline Corrected Total & 5165.064 & 98 & & & \\
\hline
\end{tabular}

a R Squared $=.470($ Adjusted R Squared $=.350)$

Table 5.

\begin{tabular}{|c|c|c|c|c|c|}
\hline Source & $\begin{array}{c}\text { Type III Sum } \\
\text { of Squares }\end{array}$ & $\mathrm{df}$ & mean Square & $\mathrm{F}$ & $\mathrm{p}$ \\
\hline Corrected model & $9315.774(\mathrm{a})$ & 18 & 517.543 & 3.883 & .000 \\
\hline Intercept & 386.532 & 1 & 386.532 & 2.900 & .092 \\
\hline dormitory & 5957.939 & 17 & 350.467 & 2.629 & .002 \\
\hline Based scores & 2112.926 & 1 & 2112.926 & 15.853 & .000 \\
\hline Error & 10662.626 & 80 & 133.283 & & \\
\hline Total & 448987.304 & 99 & & & \\
\hline Corrected Total & 19978.400 & 98 & & & \\
\hline
\end{tabular}

a R Squared $=.466$ (Adjusted R Squared $=.346$ )

Table 6 .

\begin{tabular}{|c|c|c|c|c|c|}
\hline Source & $\begin{array}{c}\text { Type III Sum } \\
\text { of Squares }\end{array}$ & df & mean Square & F & $\mathrm{p}$ \\
\hline Corrected Model & $8062.818(\mathrm{a})$ & 18 & 447.934 & 3.476 & .000 \\
\hline Intercept & 1146.524 & 1 & 1146.524 & 8.898 & .004 \\
\hline dormitory & 6608.093 & 17 & 388.711 & 3.017 & .000 \\
\hline Based scores & 1112.547 & 1 & 1112.547 & 8.634 & .004 \\
\hline Error & 10308.639 & 80 & 128.858 & & \\
\hline Total & 470840.262 & 99 & & & \\
\hline Corrected Total & 18371.457 & 98 & & & \\
\hline
\end{tabular}

a R Squared $=.439($ Adjusted R Squared $=.313$ ) 
Table 7.

\begin{tabular}{|c|c|c|c|c|c|}
\hline Source & $\begin{array}{c}\text { Type III Sum } \\
\text { of Squares }\end{array}$ & df & Mean Square & F & $\mathrm{p}$ \\
\hline Corrected model & $11062.575(\mathrm{a})$ & 18 & 614.587 & 3.233 & .000 \\
\hline Intercept & 479.880 & 1 & 479.880 & 2.524 & .116 \\
\hline dormitory & 9047.644 & 17 & 532.214 & 2.800 & .001 \\
\hline Based scores & 1704.355 & 1 & 1704.355 & 8.965 & .004 \\
\hline Error & 15208.775 & 80 & 190.110 & & \\
\hline Total & 424020.782 & 99 & & & \\
\hline Corrected Total & 26271.350 & 98 & & & \\
\hline
\end{tabular}

a R Squared $=.421$ (Adjusted R Squared $=.291$ ) 